\title{
Doing good when times are bad: the impact of CSR on brands during recessions
}

\author{
Abhi Bhattacharya \\ Faculty of Economics and Business, Rijksuniversiteit Groningen, Groningen, \\ The Netherlands \\ Valerie Good \\ Department of Marketing, Michigan State University, East Lansing, \\ Michigan, USA, and \\ Hanieh Sardashti \\ Department of Marketing, University of North Florida, Jacksonville, Florida, USA
}

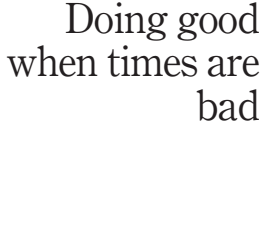

2049

\begin{abstract}
Purpose - This paper aims to determine what the brand performance consequences of corporate social responsibility (CSR) activities would be during times of recession for well-known brands.

Design/methodology/approach - Based on signaling theory, this paper investigates if CSR activities serve to signal higher brand value for consumers via perceptions of better quality and greater differentiation, specifically during recessions. This study incorporates a representative longitudinal sample of known US firms for the analyses, which is accomplished through generalized method of moments estimations.

Findings - The findings empirically demonstrate that CSR initiatives during recessions are actually associated with increased perceptions of brand value. More specifically, during recessions, CSR initiatives such as charitable contributions provide a signal to customers of higher brand quality.
\end{abstract}

Research limitations/implications - This study did not control for the costs of doing specific CSR activities that may be less visible to consumers.

Practical implications - While individual firms or managers may not be able to prevent recessions from happening, they can limit the negative impact of recessions on their performance by engaging in CSR activities (or refrain from cutting back) during these times.

Social implications - Because CSR initiatives during recessions result in more favorable consumer perceptions of the brand, engaging in CSR aligns both social and managerial interests, owing to the economic gains from CSR investments.

Originality/value - During times of recession, some critics indicate that CSR may be an unaffordable luxury. On the contrary, this research shows that managers may want to consider CSR activities as a means of increasing the value of their brands, especially during economic recessions.

Keywords Corporate social responsibility (CSR), Brand value, Recession, Quality, Differentiation

Paper type Research paper

(C) Abhi Bhattacharya, Valerie Good and Hanieh Sardashti. Published by Emerald Publishing Limited. This article is published under the Creative Commons Attribution (CC BY 4.0) licence. Anyone may reproduce, distribute, translate and create derivative works of this article (for both commercial \& non-commercial purposes), subject to full attribution to the original publication and authors. The full terms of this licence may be seen at http://creativecommons.org/licences/by/4.0/ legalcode

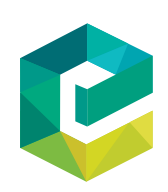

European Journal of Marketing Vol. 54 No. 9,2020 pp. $2049-2077$ Emerald Publishing Limited 0309-0566 DOI 10.1108/EJM-01-2019-0088 
EJM

54,9

2050

\section{Introduction}

Corporate social responsibility (CSR) has been recognized as a key driver of firm success, with more than half of Fortune 500 companies producing distinct CSR reports and assigning senior executives the responsibility for CSR initiatives (Keys et al., 2009). A consistent, strong body of evidence links CSR to future firm financial performance (Oh et al., 2016; Kang et al., 2016; Yim et al., 2019). Prior research defines CSR as "actions that appear to further some social good, beyond the interests of the firm and that which is required by law" (McWilliams and Siegel, 2001, p. 117; Lindgreen et al., 2012, p. 967). While not required by law, many firms have embraced CSR as a major component of their overall strategy (Mishra and Modi, 2016). Consumers and other stakeholders (such as employees, channel partners and regulators) may pressure a firm to conduct itself responsibly and actively engage in broader societal and environmental stewardship. Thus, businesses may engage in CSR to maintain social norms and legitimacy in business dealings (Lindgreen et al., 2012). Prior literature demonstrates that CSR may help consumers form impressions of the firm; hence, CSR activities may help cultivate the customer asset (Saxton et al., 2019; Guzmán and Davis, 2017).

Understandably, the notion of CSR has attracted the attention of diverse business disciplines, including marketing, management, economics and business ethics. In particular, marketing researchers have shaped much of the conversation surrounding CSR, which has been deemed an "inescapable priority" (Porter and Kramer, 2006). As CSR features can be one of the critical influencers of a corporate brand (Rust et al., 2004), it is imperative to understand how CSR initiatives affect various facets of brand performance. Though recent research has provided some evidence for the positive influence of CSR on brand loyalty (Cha et al., 2016), global brand equity (Torres et al., 2012) and brand credibility (Bigné et al., 2012), our understanding of the impact of CSR on different aspects of brand performance is still equivocal, particularly during fluctuations in the business cycle.

Certainly, recessions - essentially defined as a significant decline in economic activity spread across the economy, normally visible in real GDP (National Bureau of Economic Research, 2010) - are a common occurrence in the world's major economies. Even though a recession may be triggered by a specific event (such as the subprime loan market in the USA), firms across industries, sectors and countries feel its effects. Indeed, several studies demonstrate how harshly recessions can impact the performance of firms and entire economic sectors (Stock and Watson, 2012; Dekimpe and Deleersnyder, 2018). At such times, firms face declining revenues and a shortage of cash. Some expenses are difficult to reduce (such as certain operational expenses in a manufacturing firm). A natural tendency is to cut back on seemingly discretionary undertakings such as research and development and advertising to save on costs (Lamey et al., 2007). This helps firms overcome the shortfall in revenue and ward off a decline in profitability. Because CSR is often perceived as a peripheral activity and thus discretionary (Aguinis and Glavas, 2013), firm managers also may face pressure to reduce their CSR levels. Indeed, during the 2008-2009 [1] recession, some described CSR as an "unaffordable luxury" and suggested firms "tighten their belts" and only spend on core business activities (Franklin, 2008). However, no study to date specifically looks at CSR activities during a recession, especially their impact on brand value, which is a customer-level indicator of future firm performance (Srinivasan et al., 2010).

This gap is important to address for two reasons. First, based on past literature, we have reason to believe that CSR may positively affect brand value (Torres et al., 2012; Lindgreen et al., 2012). However, past research has not disentangled the differential impact of CSR on the various pillars that constitute overall brand value. Second, marketing activities - particularly, advertising - have been shown to become significantly more important to a firm's success during recessions (Özturan et al., 2014; Tellis and Tellis, 2009; O’Malley et al., 2011). While CSR 
activities may likewise follow this pattern of marketing actions that distinguish a firm from its competitors during a recession, no research has investigated this critical issue. When faced with decisions regarding which investments are essential to help a firm during recessions when revenue is often restricted, managers need to know where to allocate their resources for achieving the highest return.

To address this gap, in this study, we seek to answer the question, what are the performance consequences of brand value when firms leverage CSR during a recession. To answer this question, we investigate the impact of CSR on well-known firms' brand value in a large longitudinal panel of US firms during and after the 2008-2009 recession using generalized method of moments (GMM) estimations. In doing so, we provide the following contributions to the literature.

First, our findings reveal that on aggregate, at least for established brands, CSR has a positive impact on brand value during recessions, owing to a change in the effect of CSR on brand quality perceptions. This makes CSR an important factor in forming an impression of a company's brand, particularly during recessions. Although prior research shows that managers face many opposing tensions from performing CSR - for example, customers often pressure firms to perform CSR activities to benefit society while opposing pressures from stockholders and top management teams exist along the lines of accountability, limited resources and public governance (Lindgreen et al., 2012) - our research provides some evidence that investing in CSR as a strategic initiative aligns the interests of both customers and other stakeholders during recessions, hence giving managers positive rationale for performing CSR activities.

Second, we identify two pathways for CSR to impact brand performance. The first, based on signaling theory, shows that CSR efforts are a signal of quality to consumers, which leads to greater esteemed brand quality (during recessions). The second path is through differentiating a brand from its competitors.

Overall, we provide a more nuanced understanding of the rich literature on CSR as an integral marketing strategy. Following our analyses and findings, we offer an in-depth discussion, including actionable managerial insights, as well as directions for future research.

\section{Conceptual development and hypotheses}

The marketing literature has proposed that consumers appreciate the CSR initiatives of firms and feel good about the firm as well as themselves (Habel et al., 2016). In addition, several studies have investigated the relationship between corporate social performance and brand performance, as shown in Table 1 . Consumer behavior research clearly demonstrates that customer beliefs concerning CSR affect individual customer outcomes such as brand preference, brand loyalty and positive word-of-mouth (Klein and Dawar, 2004). However, outside of those looking at CSR-brand fit (Cha et al., 2016), extant studies highlighted in Table 1 have not often investigated when such an effect is stronger and whether such an effect varies across firms or even within firms over time. Because positive brand evaluations are often a prerequisite for ultimate financial performance, demonstrating when CSR may influence such a customer-level outcome such as brand value is important. Strong brands attract more loyal customers, buyers who are willing to pay more and higher customer lifetime value; brand value captures this added value from brands based on customer perceptions (Mizik and Jacobson, 2008). Because brand associations and strengths are more lasting than short-term financial performance (Wood, 2000), firms should be more attune to these outcomes when making strategic decisions such as CSR. 
EJM
54,9

2052

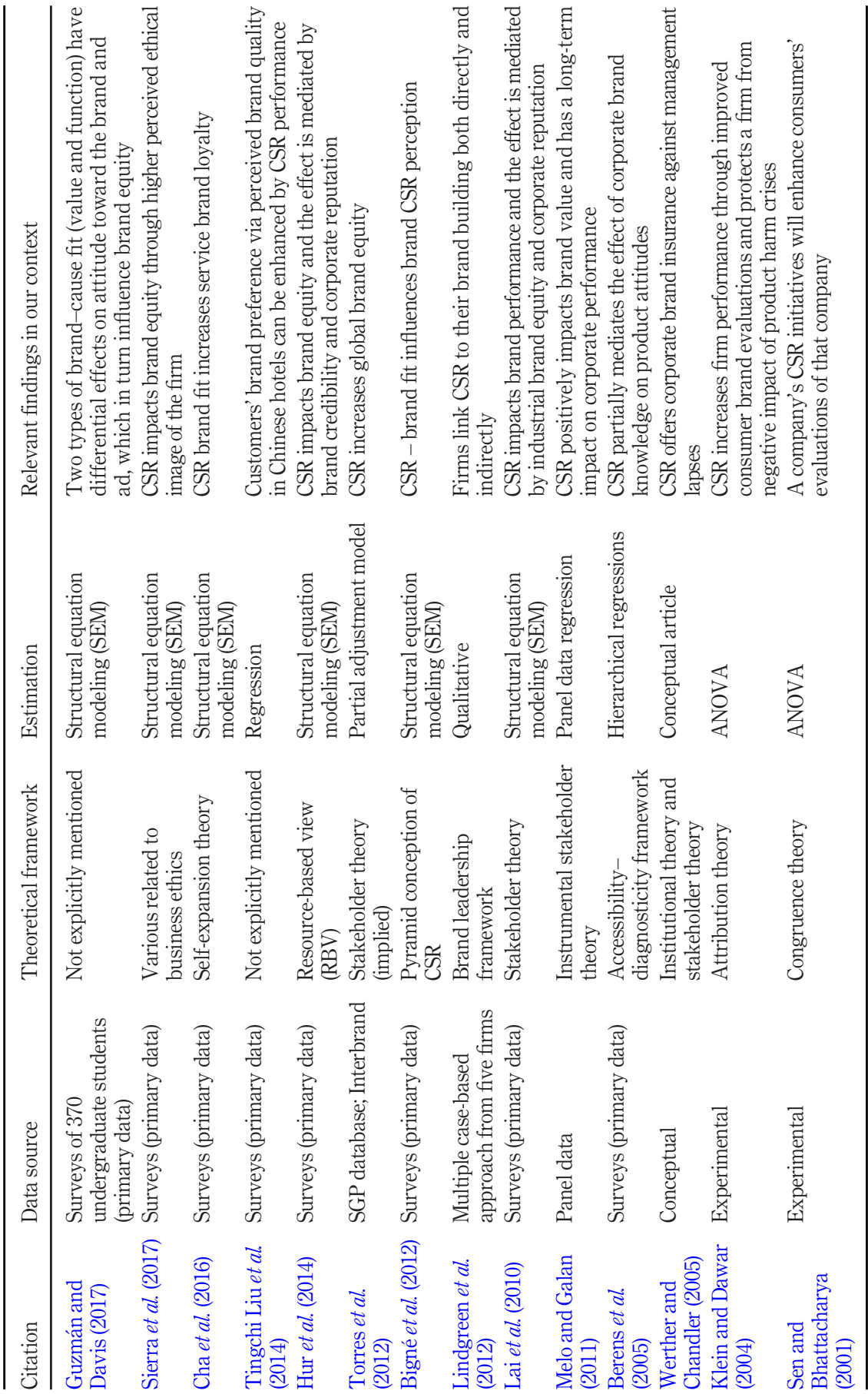

Table 1.

A literature review on CSR and brand performance by year 


\section{Impact of corporate social responsibility on brand value}

One of the largest and most widely accepted valuation models for brands is the Young and Rubicam Brand Asset Valuator (Y\&R BAV), which includes four pillars or central brand attributes (Datta et al., 2017; Mizik and Jacobson, 2014, 2008). They are (in alphabetical order): differentiation, esteem, knowledge and relevance. Differentiation is the perceived distinctiveness of the brand and reflects its ability to stand out from competition (Mizik and Jacobson, 2008). Esteem reflects the level of respect, deference and regard a consumer holds for a given brand based on perceptions of overall brand quality, which is related to being reliable and a leader in its category (Mizik and Jacobson, 2008). Knowledge accounts for customer awareness, recall and recognition of the brand (Mizik and Jacobson, 2008). Finally, relevance reflects the degree to which a brand is personally appropriate to a consumer (Mizik and Jacobson, 2008).

\section{CSR as a quality signal}

The first theorized mechanism by which CSR may lead to enhanced brand value is by signaling quality. According to signaling theory (Spence, 1978), an informed party in a market that is characterized by information asymmetry can use signals to communicate unobservable qualities to the other party. To be most effective, such signals should be visible and costly to imitate. Past literature has conveyed that signaling theory may be useful for understanding organizational CSR activities (Connelly et al., 2011). For example, information asymmetry often exists between firms and customers with regard to a firm's brand quality. Hence, Hult (2011) suggested that organizations can use CSR to:

[. . . ] signal to the marketplace what type of organization they are (e.g., an organization dedicated to sustainability practices), thus transferring information to the organization's stakeholders (most notably its customers in the marketplace) and resolving the information asymmetry (p. 518).

Past literature has indeed used signaling theory in the context of CSR (Thorne et al., 2017; Saxton et al., 2019; Yim et al., 2019); however, prior studies have not examined if CSR provides a signal of greater brand quality to customers during specific times. Moreover, articles that do involve signaling theory and CSR are rare, leading to a specific recent call for papers investigating the impact of CSR from a signaling perspective (Zerbini, 2017).

Often, consumers may have a difficult time estimating the "true" quality of a brand because of inexperience, lack of motivation or insufficient knowledge about the brand (Jin and Leslie, 2003; Kirmani and Rao, 2000). While brand quality is normally experienced only through the consumption experience, prior research demonstrates that consumers can engage in an information search and use this information to inform their decisions and ultimately arrive at a certain perceived level of quality, which may or may not be close to the true quality level (Brucks et al., 2000). Therefore, past literature emphasizes the distinction between "true" quality and "perceived" quality, with the latter having a stronger effect on overall perceived value and purchase intentions (Erdem and Swait, 2004). To aid consumers in their search as well as predispose customers favorably toward a brand (i.e. increase the perceived quality of the brand), firms engage in marketing activities that inform consumers about the brand quality (Hennig-Thurau et al., 2006). From this perspective, firms may use their CSR activities as a signal of higher quality to consumers, which reduces information asymmetry.

By engaging in CSR activities, firms can signal an elevated level of quality of the firm's internal processes and beliefs, thus creating a "halo effect" on the brand (Klein and Dawar, 2004). This may occur through two complementary signals. First, consumers may reasonably think that taking care of society implicitly means taking care of customers (Nicolau, 2008). CSR investments may signal the motivations of the firm and its emphasis on
Doing good when times are bad

2053 
creating a better society and/or that the firm has much to lose by offering inferior brands that would damage customer goodwill. Thus, CSR may increase consumers' overall trust in the brand and the credibility of the brand's claims. Second, CSR activities may convince consumers that the brand is of higher quality because they signal greater management competency and greater resources (McWilliams and Siegel, 2001). Consumers may see investments in CSR - such as a charitable donation - and assume that the firm has solid leadership and accumulated slack resources to spend and therefore must not need to save the money on quality and safety improvements (i.e. customers perceive those have already been well established by the firm). In combination with the definition of esteem relating to the consumers' perception of overall quality, CSR should signal a firm's confidence in and commitment to its brand's superior quality:

H1. CSR positively affects perceived brand quality.

\section{Corporate social responsibility as a tool to differentiate}

Another benefit of CSR initiatives is the ability companies have to differentiate their brands (Hsu, 2012). Brand differentiation is important because it creates barriers to entry and improved customer loyalty, as well as increased purchase frequency (Erdem and Swait, 2004). According to Kay (2006, p. 744), "branding is about being different" so consumers can make distinctions between products and services and base purchase decisions accordingly. Past literature has shown that effective employment of CSR initiatives by managers can differentiate brands from their competitors through excelling in their social responsibilities (Smith and Higgins, 2000). A brand can create a certain level of association with CSR best practices by embodying itself with CSR attributes (such as "hybrid" cars) or by using CSRrelated resources in its production process and organizational policies (such as "free trade" coffee) (Hsu, 2012; McWilliams and Siegel, 2001). These qualities may then differentiate a brand by appealing to ethical values within and across customer segments (Van de Ven and Jeurissen, 2005). In fact, past research has theorized that manufacturers have an opportunity to differentiate their brand through their investments in CSR and that these CSR investments become even more impactful for firm financial performance as competition increases (Madden et al., 2012; Neville et al., 2005). This makes CSR an integral element in a firm's differentiation strategies and a form of strategic investment under managerial control, similar to R\&D and advertising (Gardberg and Fombrun, 2006; McWilliams et al., 2006). With differentiation defined as the perceived distinctiveness of the brand and its ability to stand out in the marketplace, we predict the following:

\section{H2. CSR positively affects brand differentiation.}

Ex ante we do not expect an effect of CSR on either knowledge or relevance for a few reasons. First, previous research has highlighted that to esteem a brand, it must already be known (de Mortanges and van Riel, 2003). For the signal of CSR to be regarded, consumers must be aware that the brand exists to be seeking or deciphering the cue. Moreover, the brands in our secondary data sample are all well known. Thus, CSR efforts are not going to make known that which is already known, in or out of a recession. In addition, with respect to brand relevance, we argue that the impact of CSR may not be universal. While CSR may make the brand more relevant to a group of customers, it may also make the brand less relevant to other groups. Hence, the overall impact on brand relevance may be minimal. However, to be thorough in our empirical analyses, we test for an effect for these two pillars 
to confirm our suspicions that the effect on brand value is being driven by our hypothesized relationships of esteemed brand quality and differentiation.

Overall, we expect that CSR should increase both perceived brand quality and differentiation while not decreasing brand relevance and knowledge. As mentioned, prior research provides some indication that to esteem a brand's quality requires that consumers are aware of and can recall the brand (De Mortanges and Van Riel, 2003). Thus, knowledge of the brand is assumed to already have taken place. Likewise, some evidence exists showing that differentiation and relevance can work in tandem, which has been called "brand strength" in past literature (De Mortanges and Van Riel, 2003). Because uniqueness and specifically differentiation in the consumers' memory between associations with one brand and those of another brand has been shown to reduce brand substitution (Rego et al., 2009), we predict that the differentiation from doing CSR activities will have a positive impact on the total brand value. We thus presume an overall positive impact of CSR on brand value, driven primarily by the impact on perceived brand quality and differentiation.

Moreover, CSR is increasingly becoming a core component of a brand besides a range of traditional product-related brand "features" such as quality and styling (Werther and Chandler, 2005). A major assumption behind adopting CSR activities centers on the notion that customers reward good corporate citizenship through greater, more sustained patronage (Luo and Bhattacharya, 2006). As CSR activities create goodwill, consumers who are a core constituent of the broader society may be directly or indirectly impacted by a firm's CSR initiatives, which may engender stronger attachment toward the firms' offerings and brand. Taken together, we predict the following:

\section{H3. CSR positively affects brand value.}

\section{Impact of recession}

Recessions are an inevitable part of the overall business cycle. While unpleasant, recessions can offer opportunities if handled strategically. The recession that forms the context of our study was induced by the collapse of the derivative market and subsequently the housing market. The so-called Great Recession of 2008-2009 (Han and Goetz, 2015) was characterized by the most severe year-over-year decline in consumption the USA had experienced since 1945. The consumption slump was extensive (De Nardi et al., 2011) and firms found themselves struggling to generate sales, in large part because of increases in the price sensitivity of consumers, many of whom had lost or were struggling to retain their employment (van Heerde et al., 2013).

Marketing actions and investments to protect or even increase perceived brand value likely gain in importance during recessions. While CSR could serve as a strategic marketing action, performing CSR activities during a recession could create a conundrum for firms. From one perspective, CSR activities may act as a calculated initiative to differentiate the firm from its competitors. Thus, CSR initiatives during a recession could predict future brand performance. On the other hand, managers would be ill-advised to allocate scarce resources to CSR initiatives during times of crisis without any expectations of returns. Undeniably, a compelling reason for reducing strategic initiatives such as CSR or marketing investments during a recession is that sales are likely to be lower than at times of economic expansion (Tellis and Tellis, 2009). Thus, a call for future research in the marketing literature suggests investigating the effects of CSR on firm outcomes during periods of recession (Torres et al., 2012).

Past research shows that the economic environment influences both purchase decisions and brand considerations (Van Steenburg and Spears, 2011; Dekimpe and Deleersnyder, 2018). 
Extant research also suggests that the recession (perhaps extendable to recessions in general) forced many consumers to re-evaluate the brands they buy, primarily on the consideration of whether or not "value" was part of the brand's promise (Raggio and Leone, 2009). Such a re-evaluation may even be positive and beneficial for brands when combined with CSR.

During recessions, consumers may find it difficult to make decisions (Dekimpe and Deleersnyder, 2018) leading them to seek stability, predictability and low risk rather than change and new experiences (Erdem et al., 2004). Previous marketing research has demonstrated that during times of economic decline, consumers typically consciously alter their spending habits - they may reduce quantities, purchase off-brands, postpone buying or make other tough choices (Green and Peloza, 2011; Lamey et al., 2007). Rather than unconscious consumption, customers begin actively seeking cues for greater value (both quality and price) to reduce the risks of purchase. Consumers take more time and effort searching for goods and search harder to determine the "true" quality of the brand during recessions (Quelch, 2008). Thus, when firms use CSR to signal quality, these signals are more likely to be discovered and contemplated during recessions when customers are actively looking for them. Furthermore, Steenkamp et al. (2010) found that during recessions, customers are more willing to pay a price premium for a brand only if they are convinced of its superior quality. Thus, during recessionary periods, when value is essential to buyers, using CSR as a signal of higher quality and better perceived value likely becomes even more important.

Second, customers may appreciate firms for not abandoning CSR investments during tough times. During a stable economy, consumers often expect companies' CSR actions to be motivated at least in part by self-interest (Ellen et al., 2006), but such attributions are less likely to be associated with the firm during recessions when consumers know that firm resources are scarcer. For this reason, CSR during recessions may also help the firm combat perceptions of unethical practices such as greenwashing - where companies often use claims that sound environmentally friendly, but are actually vague, and at times even false (Laufer, 2003). Holt et al. (2004) affirm that the biggest challenge to the effectiveness of CSR in influencing customer perceptions is that consumers regard CSR initiative as opportunistic and perceive those actions to be motivated primarily by self-interest and not by an interest in the welfare of people and the environment. Moreover, research has demonstrated that consumers will punish firms perceived as insincere in their CSR claims (Bhattacharya and Sen, 2004). On the other hand, CSR activities during recessions (when resources are more constrained) may be viewed as an authentic and true display of social responsibility and consumer stewardship.

In summary, CSR efforts by firms during recessions may provide a stronger quality signal for two reasons - consumers are more likely to look for additional cues when faced with greater risk and uncertainty in purchase as is predicated in a recession, and consumers are more likely to consider CSR efforts to be genuine and in turn appreciate and trust a brand more. Overall, we predict the following:

H4. The positive effect of CSR on perceived brand quality is stronger during a recession.

In addition to the signal of quality, CSR activities can pay off during a recession because competition for customers' attention is reduced because of firms cutting back on advertising expenses (Tellis and Tellis, 2009; Deleersnyder et al., 2009). In line with research demonstrating a positive impact of a higher share of voice with regard to advertising (Putte, 2009), we assert that when less clutter exists in the marketplace, brands should be able to stand out from the competition through their strategic initiatives related to CSR and thus differentiate more on the basis of CSR. Moreover, the 2008-2009 recession (the one we 
observe in our sample) was attributed to the unethical activities of large financial institutions (Lewis et al., 2010). When this unethical side of businesses is salient in customers' minds, CSR activities may be more visible and result in stronger positive externalities. Thus, we hypothesize the following:

H5. The positive effect of CSR on brand differentiation is stronger during a recession.

Academic research in this area generally tends to demonstrate that investments in marketing are desirable during recessions. For example, O'Malley et al. (2011) demonstrated that strong firms generally benefit from investments in marketing and suffer from cost reduction initiatives. Likewise, a strong, consistent body of evidence conveys that cutting back on advertising during a recession can hurt sales during and after the recession, without generating any substantial increase in profits (Özturan et al., 2014; Deleersnyder et al., 2009; Tellis and Tellis, 2009). To the extent that CSR be considered a marketing action, investments in CSR, even during a recession, is likely to pay off. As detailed above, we predict that both the relationship between CSR and esteemed brand quality and the relationship between CSR and brand differentiation is higher during recessions, owing in part to the stronger signal of genuineness and greater salience of such activities in the minds of consumers. We hypothesize that in a recession, CSR investments will have an even greater positive impact on brand value:

H6. The positive effect of CSR on brand value is stronger during a recession.

\section{Research design \\ Sample}

One of the most widely accepted definitions of brand equity is Keller's (1993) conceptualization, which defines brand equity as the differential preference and response to marketing effort that a product obtains because of its brand identification as compared to the same product that did not have the brand identification. Although many measures of brand equity exist, most fall under two broad measurement approaches: based on consumers' attitude toward the brand (consumer-based brand equity, hereafter "CBBE") and based on share in the marketplace (sales-based brand equity, hereafter "SBBE") (Datta et al., 2017). The CBBE is more aligned with our research context because we are interested in changes in consumers' perception of a brand. The CBBE is affiliated with stated consumer preferences more than measures that include product market (such as category likeability) and financial market (such as firm reputation) indicators. Hence, the CBBE is most closely linked to the stakeholder we investigate in this paper - consumers. Over the years, several consulting companies have developed their own CBBE constructs and measures. Important examples include Young and Rubicam's Brand Asset Valuator (BAV), YouGov's Brand Index, Millward Brown's Brand Dynamics and Harris Interactive's EquiTrend. These syndicated databases use large-scale consumer surveys to measure perceptions of brands along multiple dimensions. While each CBBE system has its own measures (and perhaps idiosyncrasies), they tap into many of the same or related dimensions, making them largely interchangeable, as pointed out by Keller (2001).

Thus, we chose to use Young and Rubicam's BAV to obtain publicly traded mono-brand firms [2]. Young and Rubicam collects brand-related data from samples of 1,200 or more respondents each quarter from a panel of 15,000 US consumers, using a 45-min survey. The $\mathrm{BAV}$ is one of the few sources of brand value data that span more than 10 years and has been used in prior research (Datta et al., 2017; Mizik and Jacobson, 2014, 2008). To construct 
the sample, we matched firms from the BAV metrics survey with annual social responsibility data from Kinder, Lydenberg and Domini and Co., Inc. (KLD). KLD measures how well the firm did on seven particular CSR categories, including product, human rights, environment, employee relations, diversity, corporate governance and community engagement. For each of these seven categories, KLD offers a rating of the firm's strengths and concerns. We then combined this data set with accounting data from COMPUSTAT, which collects financial information for all US listed companies from 10K/10Q disclosures. The time-series unit of analysis for our study is the fiscal year because our social responsibility data were only available annually. Because BAV brand metrics are measured quarterly, we aggregated the BAV brand metrics to an annual value by simply using the mean of the metric averaged over quarters [3].

Our final sample consists of data for 137 public companies, including 19 industries, during a 9-year period between 2007 and 2015 with a total of 454 firm-year observations (115 for recession years). The years of recession we study are 2008 and 2009. Our available data is an unbalanced panel because not all brands are included in every annual edition of the BAV survey, and not all companies appear in KLD for the duration of our sample. We dealt with missing data using list-wise deletion.

\section{Measures}

Dependent variable. Brand Value. We use the overall brand asset metric constructed by Y\&R's BAV as our measure of brand value. A well-established measure, the BAV, has been shown to be an important predictor of the financial valuations and performance of brands and is a widely accepted metric of brand value (Datta et al., 2017; Mizik and Jacobson, 2014, 2008). The BAV's overall brand asset metric is the sum of brand strength and brand stature ranging from 0 to 36 . Brand stature ranging from 0 to 9 relates to brand knowledge and esteem, whereas brand strength ranging from 0 to 4 relates to brand differentiation and relevance. In summary, the overall brand asset metric combines cognitive and emotional capital of a brand with its vitality and therefore provides a more comprehensive measure of brand value (Lovett et al., 2014). We use the BAV's measure of brand esteem (the level of respect, deference and regard a consumer holds for a given brand) as our proxy for esteemed brand quality and differentiation (the level of uniqueness or distinctness of a given brand) as our measure of differentiation (Mizik and Jacobson, 2008). The measures knowledge (familiarity with the brand) and relevance (consumers' perceptions of personal relevance and appropriateness of the brand) were also used in our model to confirm our predictions that the first two facets were driving the effects to increased brand value (Mizik and Jacobson, 2008). Brand value is the sum of brand stature and strength (i.e. the additive total of knowledge, esteem, differentiation and relevance).

Independent variables. Corporate social responsibility (CSR). We obtained the CSR scores from the KLD data base. Following prior research, we assume all strength indicators as CSR (Kashmiri and Mahajan, 2010), the sum of which provides a measure of the total CSR.

Recessionary year. We consider years 2008 and 2009 as the recessionary period on the basis that these years showed a negative change in gross GDP (Gregg and Wadsworth, 2010).

Control variables (firm level). We used six controls to capture the ability and willingness of firms to do CSR during and outside of recessions.

CSR history. We consider the number of years that a firm has been part of the KLD database as a control for a firm's history of social responsibility practices. This measure is used to account for managerial emphasis on CSR practices. A firm that has historically practiced CSR may face diminishing returns with regard to the impact of CSR on its brand 
value or may be unlikely to forgo its CSR practices even if faced with adverse returns. For instance, research has shown that organizations experience long periods of strategic persistence and reluctance to change (Fang et al., 2014). Such CSR persistence may also be because of managers perceiving CSR to be a cost of competition, i.e. if the firm reduces or stops doing CSR, there may be an adverse effect. Hence, we control for the firm's CSR history.

Firm size. We calculate firm size as the natural logarithm of a firm's total assets. This control allows us to account for efficiencies of scale as well as a potential surplus of resources, which may impact both a firm's propensity to engage in CSR and the resources the firm has to drive greater brand value. Prior research has indicated that firm size is indeed a driver of CSR and that very small and very large firms are unequally motivated to participate in CSR (Udayasankar, 2008).

Financial leverage. Firm financial leverage is the ratio of long-term book debt to total assets (Thomas, 2002). Financial leverage may determine the financial strength and freedom the firm possesses, which may in turn impact its ability and willingness to continually engage in CSR through the recession.

Firm liquidity. Firm liquidity is the current ratio of the firm that measures a company's ability to pay short-term and long-term obligations. It is calculated as the ratio of firms' current total assets to its current total liabilities. Like liquidity, leverage also may determine the financial slack the firm possesses (Ang and Smedema, 2011), which may affect its ability to engage in CSR through the recession.

$R \& D$ spending. R\&D spending is obtained as a line item (Item XRD) in COMPUSTAT. Following Rothenberg and Zyglidopoulos (2007), who stated that R\&D intensive firms are likely to engage more in CSR, we include R\&D spending as a control.

Advertising spending. Advertising spending is obtained as an expense (Item XAD) in COMPUSTAT. Following McWilliams and Siegel (2001), who showed that advertising can often be a substitute for CSR in terms of building reputation and that firms may choose to do one instead of the other, we include advertising spending as a control. Because we already control for firm assets (to account for firm size), we use an absolute measure of advertising and R\&D spending instead of a measure relative to the firm's total assets, as has been used sometimes in past literature (Luo and Bhattacharya, 2009).

We report the details of the databases and the variable construction in Table 2 and the correlation matrix and descriptive statistics in Table 3.

\section{Model development}

Our data set includes both cross-sectional and temporal dimensions, and as such, it calls for suitable panel data techniques for analysis. Because the number of firms $(n)$ is larger than the time period of our analyses $(t)$, we do not use a traditional time series estimator (Blundell and Bond, 2000). We instead estimate our hypotheses by using the dynamic panel GMM estimation (for a full description of this method, see Arellano and Bond, 1991), which accounts for potential sources of endogeneity, firm-specific effects, dynamic dependent variables, heteroskedasticity and serial correlation within firms (Levine et al., 2002). Such a GMM estimator has been used in the past literature in marketing when the data set is a longitudinal panel and endogeneity may be of concern (Rego et al., 2013; Tuli et al., 2010). In our context, while we include variables that may influence both CSR and brand value (such as firm size) as covariates, potentially endogeneity could remain. For instance, previous research has found that the fit between the brand and CSR effort has an effect on consumer attitudes, responses, perceived brand value and brand loyalty (Bigné et al., 2012; Cha et al., 2016) and secondary data does not easily allow us to account for such an unobserved
Doing good when times are bad

2059 


\begin{tabular}{|c|c|c|c|c|}
\hline $\begin{array}{l}\text { EJM } \\
549\end{array}$ & Variable & Definition & Data source & Literature support \\
\hline \multirow{3}{*}{2060} & CSR & $\begin{array}{l}\text { A mean score of social strengths for } \\
\text { firm } i \text { at year } t\end{array}$ & KLD & $\begin{array}{l}\text { Kashmiri and Mahajan } \\
\text { (2010), Kotchen and Moon } \\
\text { (2012) }\end{array}$ \\
\hline & $\begin{array}{l}\text { R\&D } \\
\text { expenditure }\end{array}$ & $\begin{array}{l}\text { Research and development expenses for } \\
\text { firm } i \text { at year } t\end{array}$ & COMPUSTAT & Luo and Homburg (2007) \\
\hline & $\begin{array}{l}\text { Advertising } \\
\text { expenditure }\end{array}$ & Advertising expenses for firm $i$ at year $t$ & COMPUSTAT & McAlister et al. (2016) \\
\hline & $\begin{array}{l}\text { Financial } \\
\text { leverage }\end{array}$ & $\begin{array}{l}\text { The ratio of long-term debt to total } \\
\text { assets for firm } i \text { at year } t\end{array}$ & COMPUSTAT & Tuli and Bharadwaj (2009) \\
\hline & $\begin{array}{l}\text { Firm } \\
\text { liquidity }\end{array}$ & $\begin{array}{l}\text { The ratio of firm's current total assets } \\
\text { to its current total liabilities for firm } i \text { at } \\
\text { year } t\end{array}$ & COMPUSTAT & Luo et al. (2014) \\
\hline & CSR history & $\begin{array}{l}\text { Number of years that the firm } i \text { has } \\
\text { appeared in KLD data base }\end{array}$ & KLD & \\
\hline & Brand value & BAV's brand value for firm $i$ at year $t$ & $\begin{array}{l}\text { BAV } \\
\text { Consulting }\end{array}$ & $\begin{array}{l}\text { Mizik and Jacobson (2008) } \\
\text { Lovett et al. (2014) }\end{array}$ \\
\hline & Firm size & $\begin{array}{l}\text { Natural logarithm of total assets for } \\
\text { firm } i \text { at year } t\end{array}$ & COMPUSTAT & Mizik and Jacobson (2008) \\
\hline $\begin{array}{l}\text { Table } 2 . \\
\text { Data and measures }\end{array}$ & $\begin{array}{l}\text { Recessionary } \\
\text { year }\end{array}$ & $\begin{array}{l}\text { We consider } 2008 \text { and } 2009 \text { as } \\
\text { recessionary years }\end{array}$ & & $\begin{array}{l}\text { Kashmiri and Mahajan } \\
\text { (2010) }\end{array}$ \\
\hline
\end{tabular}

variable. Further, the effectiveness of CSR may depend on if the consumer (the focus of such activities) or indeed the market is aware of these activities - yet another unobserved variable in our context. Hence, an instrumental variable approach is necessary.

We are interested in the following equation:

$$
y_{i, t}=\alpha y_{i, t-1}+\beta^{\prime} X_{i, t}+\beth_{i}+\varepsilon_{i, t}
$$

where $i$ stands for firm, $t$ stands for time in years, $y_{i, t}$ the brand value of firm $i$ at time $t, X_{i, t}$ is the set of explanatory variables (such as prior years' brand value, firm size and advertising expenses), including the variable of interest $-\mathrm{CSR}, \beth_{i}$ captures unobserved firm fixed-effects and $\varepsilon_{i, t}$ is a random error term representing all unobserved influences on CSR and brand value, respectively. Parameter $\alpha$ reflects persistence in the process of adjustment toward equilibrium, whereas $\beta$ gives the short-run effect of $X$ on $y$ given $y_{t-1}$, with the long-run effect given by $\beta /(1-\alpha)$. To eliminate firm-specific effects, we take the first difference and arrive at:

$$
\Delta y_{i, t}=\alpha \Delta y_{i, t-1}+\beta^{\prime} \Delta X_{i, t}+\Delta \varepsilon_{i, t}
$$

By construction, in equation (2), the lagged difference in brand value is correlated with the error term, which along with the potential endogeneity of the explanatory variables $X$, requires the use of instrumental variables (IV). The GMM difference estimator uses the lagged levels of the explanatory variables as IVs, provided that the error term is not serially correlated and that the lagged levels of the explanatory variables are weakly exogenous. To calculate the difference estimator, the following moment conditions must be used: 

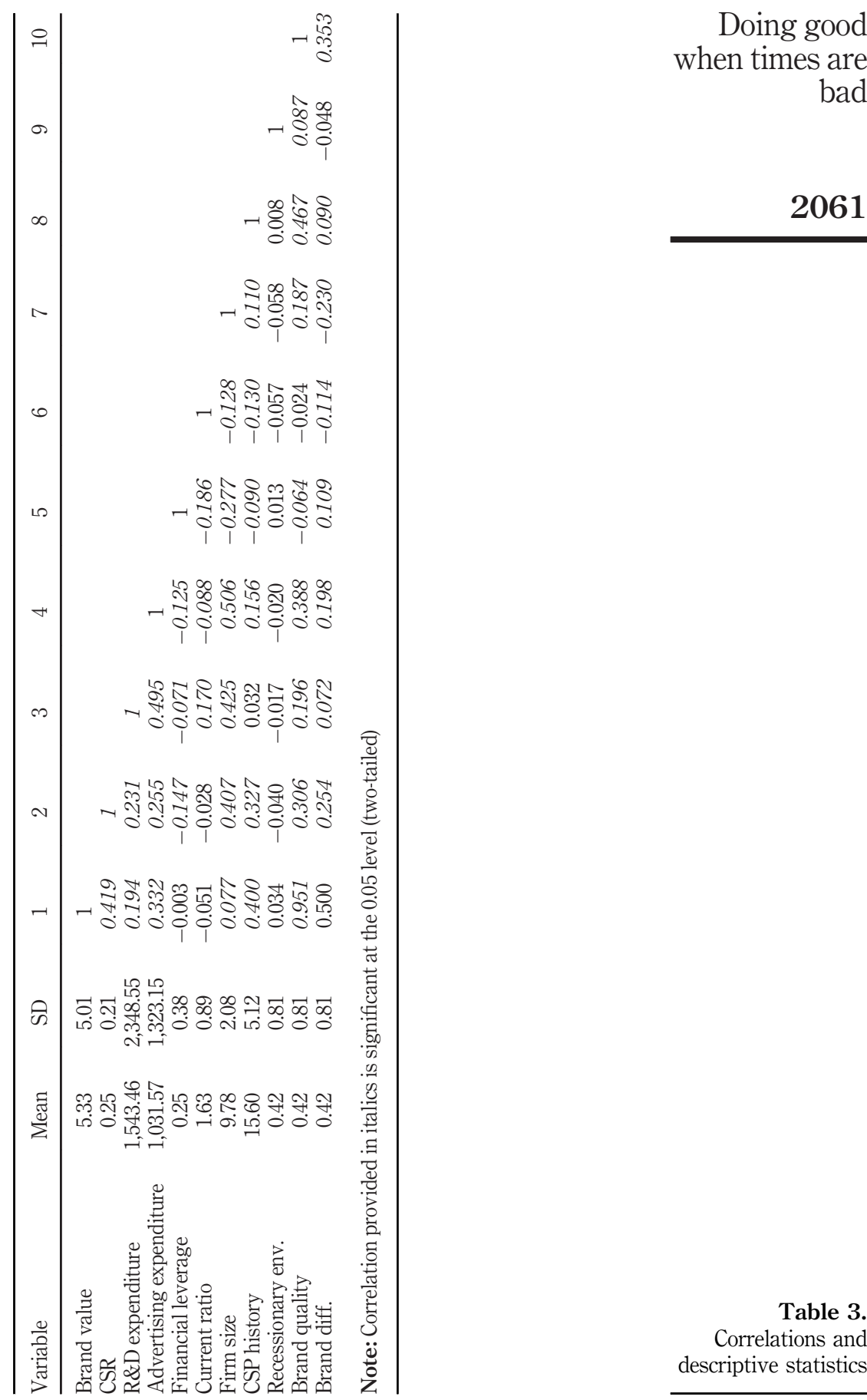
bad 


$$
\begin{aligned}
& E\left(y_{i, t-s} \Delta \varepsilon_{i t}\right)=0 \text { for } s \geq 2 ; t=3, \ldots T, \\
& E\left(X_{i, t-s} \Delta \varepsilon_{i t}\right)=0 \text { for } s \geq 2 ; t=3, \ldots T .
\end{aligned}
$$

Following Blundell and Bond (1998), the difference estimator is further combined with an estimator in levels to develop a system estimator:

$$
E\left[y_{i, t+p} \beth_{i}\right]=E\left[y_{i, t+q} \beth_{i}\right] \text { and } E\left[y X_{i, t+p} \beth_{i}\right]=E\left[X_{i, t+q} \beth_{i}\right] \text { for all } p \text { and } q
$$

A couple of specification tests may be used: the Arellano - Bond test to confirm that the error term of the difference equation is not serially correlated, and the Sargan test to confirm that the instruments are valid (here this is the Hansen J test, which is robust to heteroskedasticity and autocorrelation within panels). Valid instrumentation requires that the Hansen J test be consistent in not rejecting the null hypothesis (Roodman, 2009).

Because none of the variables are heavily skewed, we do not transform any of them. Variance inflation and condition indices statistics (the highest VIF being 2.71 and a CI of 14.1) are well below standard cutoffs, which indicate no particular problems with multicollinearity.

We use the following full model specifications to test the hypotheses concerning the effect on brand value:

Nonrecession (H3):

$$
\begin{aligned}
\text { Brand Value }_{i, t+1}= & \alpha_{0}+\alpha_{1} \text { Brand Value }_{i, t}+\alpha_{2} \text { CSR }_{i, t}+\alpha_{3} \text { Firm Size }_{i, t} \\
& +\alpha_{4} \text { CSR History }_{i, t}+\alpha_{5} \text { R\&D }_{i, t}+\alpha_{6} \text { Advertising }_{i, t} \\
& +\alpha_{7} \text { Financial Leverage }_{i, t}+\alpha_{8} \text { Financial Liquidity }_{i, t} \\
& +\alpha_{9} \text { Recessionary Year }_{t}+\beth_{i}+\varepsilon_{i, t}
\end{aligned}
$$

Recession (H6):

$$
\begin{aligned}
\text { Brand Value }_{i, t+1}= & \alpha_{0}+\alpha_{1} \text { Brand Value }_{i, t}+\alpha_{2} \text { CSR }_{i, t}+\alpha_{3} \text { Firm Size }_{i, t} \\
& +\alpha_{4} \text { CSR History }_{i, t}+\alpha_{5} R \& D_{i, t}+\alpha_{6} \text { Advertising }_{i, t} \\
& +\alpha_{7} \text { Financial Leverage }_{i, t}+\alpha_{8} \text { Financial Liquidity }_{i, t} \\
& +\alpha_{9} \text { Recessionary Year }_{t}+\alpha_{10} \text { CSR }_{i, t}{ }^{*} \text { Recessionary Year }_{t}+\beth_{i}+\varepsilon_{i, t}
\end{aligned}
$$

In the equation, $i$ indicates the firm, $t$ refers to time (year), and $\varphi_{i}$ and $\varepsilon_{i t}$ are the random error terms that represent all the unobserved influences on brand value. In our model, we controlled for firm size, financial leverage, liquidity ratio, CSR history, advertising, and R\&D expenditure that would potentially influence both the willingness and ability of the firm to invest in CSR and/or potentially influence the brand value of the firm. To test our other hypotheses, we changed the outcome variable from brand value to its composite parts (specifically, quality and differentiation). We likewise confirm no significant effects for relevance and knowledge in the same way. 


\section{Results}

Table 4 summarizes the estimates obtained from the models to test our hypotheses concerning CSR.

Our results show that in stable economic conditions, CSR is positively related to brand value $(\beta=0.049, p<0.1)$. While the relationship between CSR and brand quality did not reach statistical significance $(\beta=0.015, p>0.1)$, that with differentiation is positive and statistically significant $(\beta=0.121, p<0.001)$. The findings do provide support for our hypothesis that the effect of CSR on brand value is strengthened during recession, as the positive effect is significant $(\beta=0.112, p<0.001)$, and we find evidence of a significant positive effect of CSR on brand quality $(\beta=0.082, p<0.05)$ but not on differentiation $(\beta=0.041, p>0.1)$. Figures 1 and 2 depict these interactions.

As predicted, we do not find CSR to impact the brand dimensions of knowledge $(\beta=-0.054, p>0.1)$ and relevance $(\beta=-0.025 \mathrm{p}>0.1)$ nor a moderating effect of recession $(\beta=0.061, p>0.1 ; \beta=-0.010, p>0.1$ for knowledge and relevance, respectively) (Table 5). A summary of our hypotheses testing results is provided in Table 6.

\section{Additional results}

Model-free evidence: We obtain some model-free evidence to test the validity of our findings. We observe that the average difference in advertising spending between recessionary and nonrecessionary years is $(-) \$ 52.15 \mathrm{~m}$. This is consistent with past literature (Srinivasan et al., 2011) that says firms reduce advertising spending during recessions. The average growth in advertising expenses during nonrecessionary periods is $\$ 17.99 \mathrm{~m}$. Interestingly, we find that mean growth in CSR scores is practically nonexistent during recession (0.01) compared to periods of GDP growth (0.15). However, firms also reduced their capital expenses and number of employees (by $8 \%$ and $7 \%$, respectively). This suggests that firms looked to use a two-pronged strategy - saving on certain costs while maintaining investments in others, a strategy which might have helped firms overcome the unique challenges brought on by the recession (Ioannou and Flammer, 2019). We also observe the correlation between CSR and brand strength is stronger during recession (0.45) than during nonrecession (0.35).

\section{Robustness checks}

Alternate measures of recession: We obtained data concerning consumer confidence in the economy from the Michigan Index of Consumer Sentiment (ICS), which is a national survey of telephone interviews with households. Lower confidence is correlated with more saving, consistent with precautionary motives and decreases in expected future resources. Consumer confidence has been shown to be substantially lower during periods of economic downturns (Ludvigson, 2004). Instead of our indicator for recessionary years, we use this measure to further ascertain the robustness of our results. Doing so allows us to make our results more generalizable and increases the power of our analyses (through the use of a continuous variable). We find that the interaction term is negative and significant (i.e. the impact of CSR on brand value is stronger when consumer confidence is lower). This finding ties in with our substantive conclusions.

Simultaneous estimations: As another robustness check, we used the same equations as described before and used the different brand-level outcome variables. We know that the brand outcome variables - quality, knowledge, differentiation and relevance - are endogenous and correlated. Ignoring the violation of the assumption of independent observations may result in higher standard errors and larger Type I error, requiring an estimation technique allowing correlated errors for more efficient estimates (Cameron and Trivedi, 2013). We accomplish this 
EJM
54,9

2064
Table 4.

Impact of CSR on brand outcomes

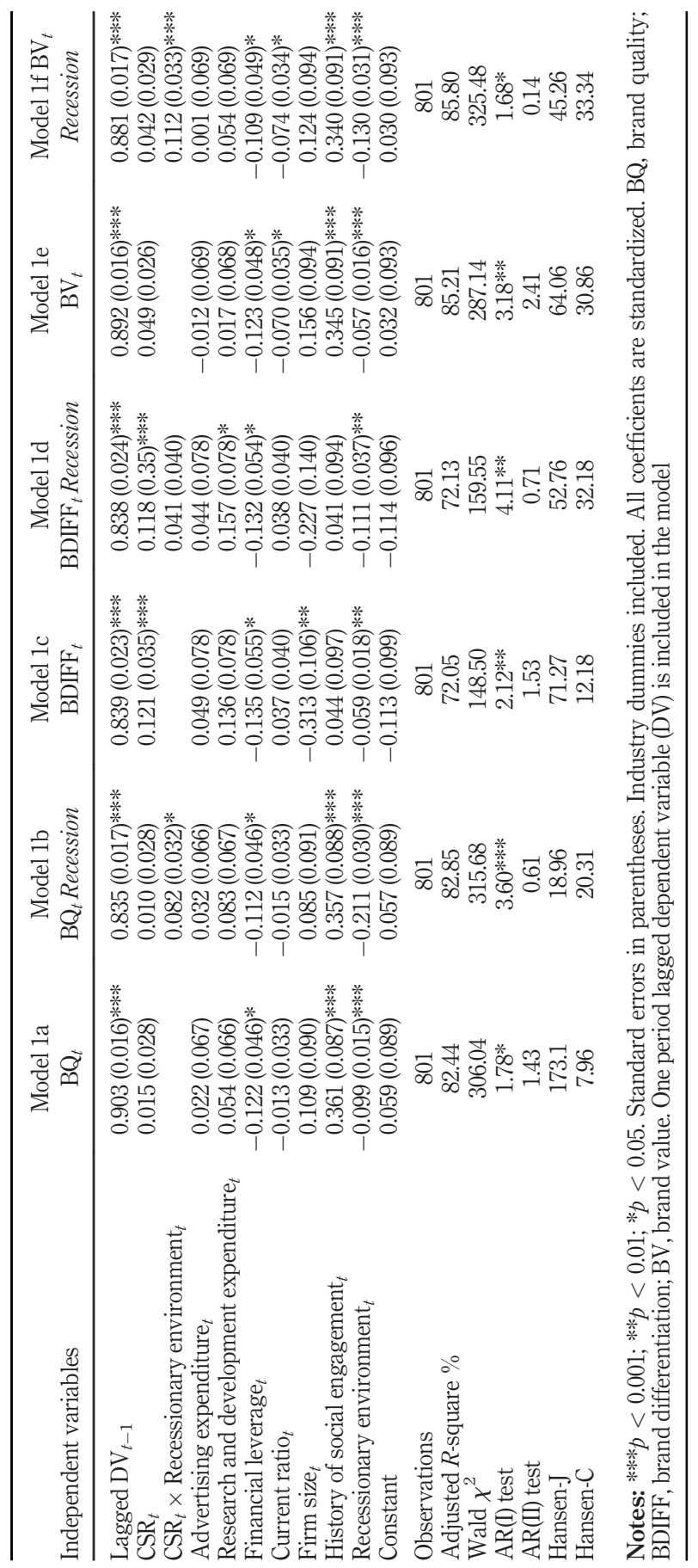


using a recursive set of three interrelated equations in which we estimate the equations jointly, using Roodman's (2009) conditional mixed process (CMP) regression technique, as implemented in Stata 15. The CMP technique is applied to a recursive system of equations to maximize a higher order multivariate normal generalization of the likelihood function to when times are account for the likely correlation among our outcome variables. We do not find any substantive difference in our results.

Subgroup regressions: In addition to estimating our model parameters using a random effects estimator, we also estimated the models using subgroup regressions. Subgroup bad regressions, which are a well-established procedure in strategic management for investigating contingencies (Peng and Luo, 2000), were conducted to test the hypotheses concerning the effects of recession. Once again, we find that our substantive results remain unchanged.

\section{Discussion}

The results of this study demonstrate some interesting findings. First, we only observe a weakly positive impact of CSR on brand value during stable economic conditions. We find that while CSR helps differentiate a brand, the impact on esteemed brand quality is nonsignificant. We also do not find any evidence that CSR increases brand relevance or knowledge, as expected. Overall, the positive impact of CSR on brand differentiation is not enough to drive a strong impact on brand value. Some past literature supports this finding.

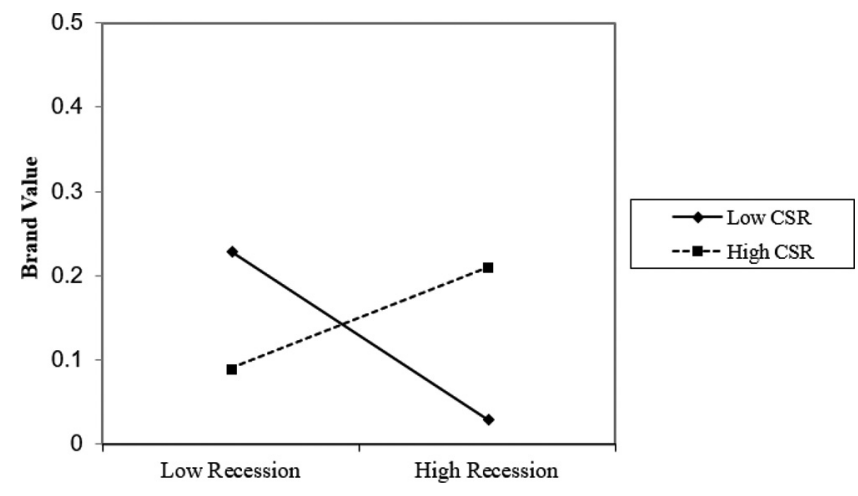

Figure 1.

Interaction of recession and CSR on

brand value (standardized)

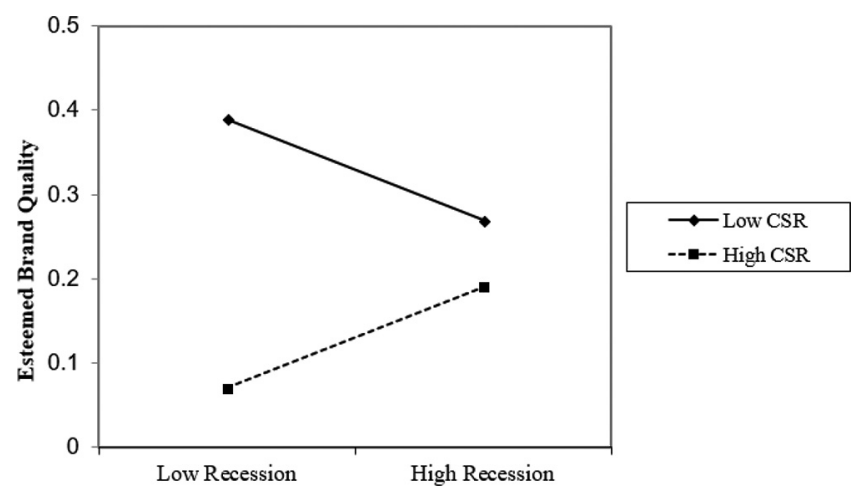

Figure 2.

Interaction of recession and CSR on esteemed brand quality (standardized) 


\section{EJM \\ 54,9}

\begin{tabular}{|c|c|c|c|c|}
\hline Independent variables & $\begin{array}{c}\text { Model 1a } \\
\text { Brand relevance }_{t}\end{array}$ & $\begin{array}{l}\text { Model 1b } \\
\text { Brand } \\
\text { knowledge }_{t}\end{array}$ & $\begin{array}{c}\text { Model 1c } \\
\text { Brand relevance }_{t} \\
\text { Recession }\end{array}$ & $\begin{array}{c}\text { Model 1d } \\
\text { Brand knowledge }_{t} \\
\text { Recession }\end{array}$ \\
\hline Lagged $\mathrm{DV}_{t-1}$ & $0.840(0.024) * * * *$ & $0.839(0.024) * * *$ & $0.961(0.012)^{* * * *}$ & $0.961(0.012)^{* * * *}$ \\
\hline $\mathrm{CSR}_{t}$ & $-0.025(0.030)$ & $-0.054(0.038)$ & $-0.017(0.019)$ & $-0.059(0.032)$ \\
\hline $\begin{array}{l}\text { CSR }_{t} \times \text { Recessionary } \\
\text { environment }_{t}\end{array}$ & & & $-0.010(0.011)$ & $0.061(0.042)$ \\
\hline Advertising expenditure $_{t}$ & $0.026(0.050)$ & $0.017(0.059)$ & $0.054(0.049)$ & $0.032(0.058)$ \\
\hline $\begin{array}{l}\text { Research and development } \\
\text { expenditure } t_{t}\end{array}$ & $0.149(0.049)^{* * *}$ & $-0.029(0.058)$ & $0.114(0.049)^{*}$ & $0.007(0.058)$ \\
\hline Financial leverage $_{t}$ & $-0.061(0.032)$ & $-0.048(0.041)$ & $-0.058(0.034)$ & $-0.035(0.041)$ \\
\hline Current ratio $_{t}$ & $-0.053(0.022)^{*}$ & $-0.113(0.028)^{* * * *}$ & $-0.053(0.022)^{*}$ & $-0.115(0.027)^{*}$ \\
\hline Firm size $t_{t}$ & $0.539(0.079)^{* * * *}$ & $0.301(0.083)^{* * * *}$ & $0.304(0.071)^{* * * *}$ & $0.274(0.083)$ \\
\hline $\begin{array}{l}\text { History of social } \\
\text { responsibility engagement }\end{array}$ & $0.167(0.119)$ & $0.206(0.102)^{*}$ & $0.346(0.099) * * *$ & $0.202(0.101)^{*}$ \\
\hline Recessionary year ${ }_{t}$ & $-0.031(0.014)^{*}$ & $-0.054(0.012)^{* * *}$ & $-0.034(0.010)^{* * *}$ & $-0.061(0.012)$ \\
\hline Constant & $0.231(0.101)^{*}$ & $0.122(0.105)$ & $0.231(0.102)^{*}$ & $0.122(0.104)$ \\
\hline Observations & 801 & 801 & 801 & 801 \\
\hline Adjusted $R$-square \% & & & & 77.95 \\
\hline Wald $\chi^{2}$ & 267.96 & 251.25 & 263.61 & 247.14 \\
\hline AR(I) test & $3.27^{* *}$ & 1.94 & $2.17^{*}$ & $2.06^{*}$ \\
\hline AR(II) test & -1.1 & -0.4 & 0.95 & -0.39 \\
\hline & 23.86 & 42.17 & 27.32 & 91.21 \\
\hline Hansen-C & 23.16 & 24.28 & 21.51 & 13.59 \\
\hline
\end{tabular}

Table 5.

Impact of CSR on knowledge and relevance brand outcomes

Notes: $* * * p<0.001 ; * * p<0.01 ; * p<0.05$. Standard errors in parentheses. All coefficients are standardized. One period lagged dependent variable (DV) is included in the model

Summary of hypotheses and results

\begin{tabular}{lccll}
\hline Hypotheses & Direction of $H$ & Result & Significance & Support for $H$ \\
\hline H1: CSR on esteemed brand quality & + & + & No & No \\
H2: CSR on brand differentiation & + & + & Yes & Yes \\
H3: CSR on brand value & + & + & At $p<0.1$ & Partial \\
H4: CSR on esteemed brand quality in recession & + & + & No & No \\
H5: CSR on brand differentiation in recession & + & + & Yes & Yes \\
H6: CSR on brand value in recession & + & + & Yes & Yes \\
\hline
\end{tabular}

For instance, Melo and Galan (2011) demonstrated that when CSR is used as an aggregated variable combining all seven qualitative areas in one construct, the effect on brand value was not significant.

Interestingly, CSR does not act as a quality signal during stable economic times. This may be because of the unwillingness of customers to look extensively for (or pay much heed to) external quality cues during stable economic times when the stakes of making a wrong purchase are lower. Further, during nonrecessionary periods, the CSR activities of firms may be less salient or believable (because of perceptions of greenwashing and greater CSR clutter). Our findings support prior research that found no direct effect between corporate associations (measured as CSR reputation) and product attitude (measured as a function of appeal, reliability and quality) (Berens et al., 2005) and no positive effect of CSR philanthropies on brand quality (Ricks, 2005). However, the results 
remain contrary to other research that did not specifically test CSR and a recession together but propose a CSR - quality link (Benlemlih, 2017; Calveras and Ganuza, 2018; Saxton et al., 2019). We contend that these inconsistencies could be because of two reasons:

(1) studies often do not distinguish between corporate reputation and brand quality; and

(2) a number of the studies that did find a positive effect of CSR on brand quality do not account for potentially unobserved firm characteristics (such as size), which could drive both CSR and brand quality (i.e. such studies do not account for endogeneity because of omitted variables).

Nonetheless, our analyses demonstrate that CSR becomes important during economic recessions and has a significant positive effect on brand value. This relationship is driven by a positive effect on esteemed brand quality. Three potential reasons may explain this finding. First, as we mentioned in prior sections, when the unethical side of businesses is more salient, customers may value CSR more as such activities indicate that the firm is aligned with customer and societal interests. Second, prior research has indicated that during recessions, customers reject affluent materialism and an emphasis on profits and instead value firms' altruistic endeavors (Flatters and Willmott, 2009). Third, the willingness for customers to look for external quality cues may be heightened during times of recession, where customers are more risk-averse and seek to obtain the best value and for the price they pay (Piercy et al., 2010; Bhattacharya et al., 2020).

While recessions moderated the CSR - brand quality relationship, we did not find an effect on the CSR - brand differentiation relationship. This is perhaps owing to an empirical reason - in our sample, we observe that during stable economic periods, firms tend to consistently increase their CSR. In recession, the firms cut back by mostly maintaining (rather than increasing) their CSR initiatives. Further, firms cut back on their advertising expenses (which we observe in our sample) and therefore may likewise cut back on advertising their CSR activities. The combined effect might result in firms not finding it any easier to stand out. To further investigate this possibility, we looked at the moderating effect for a subset of firms that continued to increase their CSR levels (where the difference in CSR scores was at least a 0.5 standard deviation) during recession. We did find a small but significant effect on differentiation then $(\beta=0.03, p<0.05)$.

\section{Theoretical implications}

The effect of CSR on corporate financial performance has been extensively studied (Yim et al., 2019; Oh et al., 2016; Kang et al., 2016; Mishra and Modi, 2016). To a lesser extent, the impact of CSR on brand-level outcomes has also been researched (Guzmán and Davis, 2017; Sierra et al., 2017; Cha et al., 2016; Torres et al., 2012). Often, the theoretical bases for these studies is stewardship (which assumes managers are motivated by financial gain), institutional theory (which conceptualizes CSR as a tool to gain consensus) or resourcebased view (RBV, which discusses CSR as a relational asset of the firm). Signaling theory, on the other hand, maintains the assumption of economic rationality and conceptualizes CSR initiatives as cueing tools that enhance the efficiency of the market and the performance of the firm (Zerbini, 2017). Moreover, signaling theory also specifies the underlying mechanism further, by pointing to the cueing process that links the CSR initiatives to the market response (Zerbini, 2017).

A call to advance signaling theory in recent literature includes examining contingency factors related to the signal (Zerbini, 2017). From this perspective, our study extends the understanding of CSR and signaling theory by showing that the receivers (i.e. consumers) are 
more primed to seek cues at certain times, or rather under certain conditions (i.e. recessions). These cues stand out more when the receiver has more at risk by making a poor choice and depending on the strength of other cues in the marketplace (such as advertising).

In addition, specific aspects of brand value that CSR can impact have not been investigated yet, to the best of the authors' knowledge. Such a study is important because CSR only affects the pillars of brand differentiation and quality, and each effect is different depending on the economy.

Moreover, Zerbini (2017) emphasized that scholarly research would benefit from an empirical analysis of the consequences of signaling through CSR initiatives and the "fundamental role that CSR plays in the generation of financial performance". This study highlights that CSR efforts impact customer-based brand equity, particularly during recessions, and the economic significance of these findings should not be underestimated. According to Mizik and Jacobson (2008), the financial market uses information contained within these investigated brand attributes to update expectations of future cash flows, which likewise impacts stock price. Additionally, Steenkamp et al. (2010) showed that in recessions, consumer shifts in demand as small as $1 \%$ point can severely dent firm profitability, which is significant enough to alter market dynamics and make market leaders respond in tangible ways. The use of CSR under such conditions can be a valuable tool for managers to increase and protect their brand and reap the rewards that ultimately ensue from having a stronger brand.

Further, our combined results provide extensive evidence and support for our conjecture that the quality signal from CSR becomes stronger in times of recession, when purchase risk is higher. Somewhat counterintuitively, we find that during recessions, by signaling brand quality and thereby reducing customer uncertainty, CSR predicts brand value. Thus, rather than cutting back on or maintaining consistent levels of CSR, firms may find it advantageous to increase their CSR efforts during recessions to increase consumers' confidence in the quality of the firm's brand. Overall, our findings suggest that we can now propose new fundamental propositions concerning CSR, including $\left(P_{1}\right)$ CSR's effect on brand value is a function of the degree to which it provides signals of a brand's quality and differentiation; and $\left(P_{2}\right)$ The quality signal of CSR is valuable in the presence of specific complementary economic conditions. These propositions provide new insights into the nature of CSR as a strategic marketing action.

\section{Managerial implications}

Managers tend to view adverse business environments such as recessions as a threat because they cannot control the situation and are likely to face financial losses (Alessandri et al., 2014). One of the common responses is the culling of expenses and activities not considered to be part of the core business. Because CSR is often not considered to be a core activity for firms, one may expect firms to withdraw their social commitments during recessions (Bansal et al., 2015). Even though managers cannot prevent recessions from occurring, a synthesis of marketing research conducted over the previous decade and a half has provided evidence that the impact of business cycles on consumers (and hence on firm and brand performance) depends to a large extent on how managers adjust their marketing mix in response to these macroeconomic swings (Dekimpe and Deleersnyder, 2018). While this research synthesis included many marketing actions, somewhat surprisingly, CSR was not part of this list. Our findings thus build upon this research and demonstrate that managers can limit the negative impact of recessions on their brand value by engaging in CSR activities (or refrain from cutting back) during difficult times. 
Our results show that even when controlling for advertising spending and firm size (which are major determinants of brand value for most firms), CSR initiatives explained significant variance in brand value outcomes. In bad economic times, marketers have been advised to change their advertising content from time-sensitive promotions to more brand-oriented messages because the economic environment does have an impact on brand loyalty (Quelch and Jocz, 2009). CSR activities in a recession may be the answer to protecting a firm's brand value and ensuring a boost in consumer perceptions of quality. This is especially important because brand quality perceptions tend to be persistent (Lamey et al., 2007), so any improvements in perceived quality might be beneficial even after the economy recovers.

During prosperous or at least stable economic periods (and to a lesser extent, even during recessions), managers may look at CSR as a way to differentiate their brand. Companies should recognize the crucial role of CSR and invest in CSR initiatives to enhance positive, strong and differentiated brand value both at the brand level by imbibing brand attributes congruent with CSR values (for instance, Sunchips has a marketing campaign "Who's Hungry for Change?" and made the first biodegradable snack bag using renewable energy) and at the firm level through companies' social and environmental actions (for instance, reducing its carbon footprint has been one of Intel's corporate goals).

For managers attempting to address challenges because of changes in consumer behavior during recessions, understanding why CSR activities are valuable can help decision-making. Economic theory posits that changes in the relationship between how much consumers are willing to pay, on the one hand, and their perception of the value they are receiving, on the other, underpin behavioral changes (Steenkamp et al., 2010). In times of economic prosperity, but even more so during recessions, managers should focus their CSR investments on aspects of CSR that lead to consumer perceptions of higher brand quality and differentiation. As such, esteemed brands may even be able to charge a higher price for their products and services.

We also find some support for our results from managerial literature and firm practices. Ioannou and Flammer (2019) report that successful companies, on average, responded to the recession by simultaneously "saving their way out of the crisis" by reducing their workforce and capital expenses and "investing their way out of the crisis" by sustaining their investments in marketing activities. Some strong brands did increase their CSR budgets. Microsoft increased its corporate tax giving as percentage of pretax profit from $2.09 \%$ in 2008 to $2.61 \%$ in 2009 (Microsoft CSR report, 2010). Disney increased its total contribution from $\$ 209 \mathrm{~m}$ in 2008 to $\$ 227.4 \mathrm{~m}$ in 2009 in the midst of financial crisis (Disney CSR report, 2008 and 2009). Perhaps not unsurprisingly, our data shows that both Microsoft and Disney managed to slightly increase their brand values $(0.8 \%$ and $1.5 \%$ increases, respectively). Considering the fact that extant research (Johansson et al., 2012) found that stronger global brands actually fared worse in a recession, our results provide an important strategic action that firms can take to prevent any losses.

\section{Limitations and future research}

Apart from the above contributions, our research has several limitations which could also serve as fruitful avenues for future research. First, we use composite CSR scores aggregated across all dimensions, while some authors (Capelle-Blancard and Petit, 2014) argue that firms may differ with regard to their emphasis on different CSR dimensions and one dimension may be more important than the other depending on firm and industry characteristics. While our moderate sample size and our desire to prevent unnecessary complexity precluded us from separating out each individual dimension of CSR and examine the fit with firm and industry characteristics, future research could investigate both the element of a strategic fit and customer preference regarding each dimension. Similarly, past research has also demonstrated the importance of fit between a brand and CSR 
(Guzmán and Davis, 2017; Moosmayer and Fuljahn, 2013). This would amount to a "fixed effect" in a model (because fit can be assumed to be a persistent characteristic of the brand), and our setup essentially just controls for it. Further, we lack secondary data concerning brand - CSR fit, though we expect that brands with a greater fit stand to benefit more from CSR initiatives, while there may be diminishing returns. Thus, future research may shed further light on this important topic.

Second, our data does not contain the amount of publicity a firm's CSR action generates, whether or not through the firm's own doing. While a firm's advertising expenses and size may partly proxy for this, we cannot control for CSR efforts that are less visible to consumers. Future research may investigate whether the visibility (or lack thereof) of CSR makes a difference in or out of recessions.

Third, although the KLD data have been used extensively in existing research (Kang et al., 2016), the CSR measures are based on expert evaluations and not actual monetary investments (Chatterji et al., 2009). Future research could replicate our findings using different CSR data, such as Sustainalytics. On a related note, our measure of brand value is consumer based and may not strictly transfer to sales. While Datta et al. (2017) note that such consumer-based measures align well with sales-based measures of brand value, there are obvious overachievers (highly regarded brands that do not garner the sales they should) and underachievers (brands that perform above their potential). Such differences could in part be explained by other marketing mix variables such as price or distribution. Future research may use other measures of brand value/equity to extend our knowledge.

Fourth, while we control for past CSR performance as a proxy for whether CSR is an integral part of the firm's activities, future research may identify whether firms that proactively engage in CSR - and where CSR is woven into the fabric of the company - have more to gain (or lose) by increasing (reducing) their CSR activities during periods of economic downturn. Likewise, researchers may wish to investigate the extent to which companies have cut back or increased their CSR during recessions and subsequent recovery to determine the effects on firm financial performance.

Fifth, past research has indicated that consumers' cognitive and affective orientation toward the economy, which is influenced by the age of the customer, may have an impact on brand loyalty (Van Steenburg and Spears, 2011). There could be other consumer characteristics that could influence the effectiveness of CSR during recessions. For instance, millennials might view CSR as a necessity for firms to engage in even during recessions, and a firm particularly targeting that demographic might achieve even greater returns from their CSR actions. Unfortunately, we do not have information involving consumer characteristics in our data set, and we leave this question as an inquiry for future research.

\section{Notes}

1. The Financial Crisis Inquiry Commission in their January 2011 report "Economics Crisis in the United States" labels the period as a Great Recession in the USA. The specific months are December 2007 through June 2009.

2. A mono-brand is a single brand that represents the bulk of the firm's business (Mizik and Jacobson, 2008). Examples of mono-brands include IBM, Yahoo, American Express, Disney, Apple and Microsoft. We select only mono-brand firms for two reasons. First, using this sample selection strategy prevents bias because of unobservable heterogeneity. For example, some brands may present a greater fit with the CSR alignment of the firm. Second, CSR initiatives are related to corporate-level performance but not subdivisions or business units. Hence, it seems appropriate to assume that customers associate CSR activities to the corporate brand as part of firm's commitment to society. 
3. In case all four quarters of data were not available, the mean is simply that of the quarters present.

\section{References}

Aguinis, H. and Glavas, A. (2013), "Embedded versus peripheral corporate social responsibility: psychological foundations", Industrial and Organizational Psychology, Vol. 6 No. 4, pp. 314-332.

Alessandri, T., Cerrato, D. and Depperu, D. (2014), "Organizational slack, experience, and acquisition behavior across varying economic environments", Management Decision, Vol. 52 No. 5, pp. 967-982.

Ang, J. and Smedema, A. (2011), "Financial flexibility: do firms prepare for recession?", Journal of Corporate Finance, Vol. 17 No. 3, pp. 774-787.

Arellano, M. and Bond, S. (1991), "Some tests of specification for panel data: Monte Carlo evidence and an application to employment equations", The Review of Economic Studies, Vol. 58 No. 2, pp. 277-297.

Bansal, P., Jiang, G.F. and Jung, J.C. (2015), "Managing responsibly in tough economic times: strategic and tactical CSR during the 2008-2009 global recession”, Long Range Planning, Vol. 48 No. 2, pp. 69-79.

Benlemlih, M. (2017), “Corporate social responsibility and firm debt maturity", Journal of Business Ethics, Vol. 144 No. 3, pp. 491-517.

Berens, G., Van Riel, C.B. and Van Bruggen, G.H. (2005), "Corporate associations and consumer product responses: the moderating role of corporate brand dominance", Journal of Marketing, Vol. 69 No. 3, pp. 35-48.

Bhattacharya, A., Good, V., Sardashti, H. and Peloza, J. (2020), "Beyond warm glow: the risk-mitigating effect of corporate social responsibility (CSR)", Journal of Business Ethics, pp. 1-20.

Bhattacharya, C.B. and Sen, S. (2004), "Doing better at doing good: when, why and how consumers respond to corporate social initiatives", California Management Review, Vol. 47 No. 1, pp. 9-24.

Bigné, E., Currás-Pérez, R. and Aldás-Manzano, J. (2012), "Dual nature of cause-brand fit: influence on corporate social responsibility consumer perception", European Journal of Marketing, Vol. 46 Nos 3/4, pp. 575-594.

Blundell, R. and Bond, S. (1998), "Initial conditions and moment restrictions in dynamic panel data models", Journal of Econometrics, Vol. 87 No. 1, pp. 115-143.

Blundell, R. and Bond, S. (2000), "GMM estimation with persistent panel data: an application to production functions", Econometric Reviews, Vol. 19 No. 3, pp. 321-340.

Brucks, M., Zeithaml, V.A. and Naylor, G. (2000), "Price and Brand name as indicators of quality dimensions for consumer durables", Journal of the Academy of Marketing Science, Vol. 28 No. 3, pp. 359-374.

Calveras, A. and Ganuza, J.J. (2018), "Corporate social responsibility and product quality", Journal of Economics and Management Strategy, Vol. 27 No. 4, pp. 804-829.

Cameron, A.C. and Trivedi, P.K. (2013), Regression Analysis of Count Data, Vol. 53, Cambridge University Press.

Capelle-Blancard, G. and Petit, A. (2014), "The weighting of CSR dimensions: one size does not fit all", Business and Society, Vol. 56 No. 6, pp. 919-943.

Cha, M.K., Yi, Y. and Bagozzi, R.P. (2016), "Effects of customer participation in corporate social responsibility (CSR) programs on the CSR-brand fit and brand loyalty", Cornell Hospitality Quarterly, Vol. 57 No. 3, pp. 235-249.

Chatterji, A.K., Levine, D.I. and Toffel, M.W. (2009), "How well do social ratings actually measure corporate social responsibility?”, Journal of Economics and Management Strategy, Vol. 18 No. 1, pp. 125-169. 
Connelly, B.L., Ketchen, D.J. and Slater, S.F. (2011), “Toward a 'theoretical toolbox' for sustainability research in marketing", Journal of the Academy of Marketing Science, Vol. 39 No. 1, pp. 86-100.

Datta, H., Ailawadi, K.L. and Van Heerde, H.J. (2017), "How well does consumer-based brand equity align with sales-based brand equity and marketing-mix response?”, Journal of Marketing, Vol. 81 No. 3, pp. 1-20.

de Mortanges, C.P. and Van Riel, A. (2003), "Brand equity and shareholder value", European Management Journal, Vol. 21 No. 4, pp. 521-527.

De Nardi, M., French, E. and Benson, D. (2011), “Consumption and the great recession”, No. w17688, National Bureau of economic research.

Dekimpe, M.G. and Deleersnyder, B. (2018), "Business cycle research in marketing: a review and research agenda", Journal of the Academy of Marketing Science, Vol. 46 No. 1, pp. 31-58.

Deleersnyder, B., Dekimpe, M.G., Steenkamp, J.B.E. and Leeflang, P.S. (2009), "The role of national culture in advertising's sensitivity to business cycles: an investigation across continents", Journal of Marketing Research, Vol. 46 No. 5, pp. 623-636.

Ellen, P.S., Webb, D.J. and Mohr, L.A. (2006), "Building corporate associations: consumer attributions for corporate socially responsible programs", Journal of the Academy of Marketing Science, Vol. 34 No. 2, pp. 147-157.

Erdem, T. and Swait, J. (2004), "Brand credibility, brand consideration, and choice", Journal of Consumer Research, Vol. 31 No. 1, pp. 191-198.

Erdem, T., Zhao, Y. and Valenzuela, A. (2004), "Performance of store brands: a cross-country analysis of consumer store-brand preferences, perceptions, and risk", Journal of Marketing Research, Vol. 41 No. 1, pp. 86-100.

Fang, C., Kim, J.H. and Milliken, F.J. (2014), "When bad news is sugarcoated: information distortion, organizational search and the behavioral theory of the firm", Strategic Management Journal, Vol. 35 No. 8, pp. 1186-1201.

Flatters, P. and Willmott, M. (2009), "Understanding the post-recession consumer", Harvard Business Review, Vol. 87 Nos 7/8, pp. 106-112.

Franklin, D. (2008), “Just good business: a special report on corporate social responsibility”, Economist Newspaper, available at: http://www.economist.com/node/10491077

Gardberg, N.A. and Fombrun, C.J. (2006), "Corporate citizenship: creating intangible assets across institutional environments", Academy of Management Review, Vol. 31 No. 2, pp. 329-346.

Green, T. and Peloza, J. (2011), "How does corporate social responsibility create value for consumers?", Journal of Consumer Marketing, Vol. 28 No. 1, pp. 48-56.

Gregg, P. and Wadsworth, J. (2010), "Unemployment and inactivity in the 2008-2009 recession", Economic and Labour Market Review, Vol. 4 No. 8, pp. 44-50.

Guzmán, F. and Davis, D. (2017), "The impact of corporate social responsibility on brand equity: consumer responses to two types of fit”, Journal of Product and Brand Management, Vol. 26 No. 5, pp. 435-446.

Habel, J., Schons, L.M., Alavi, S. and Wieseke, J. (2016), "Warm glow or extra charge? The ambivalent effect of corporate social responsibility activities on customers' perceived price fairness", Journal of Marketing, Vol. 80 No. 1, pp. 84-105.

Han, Y. and Goetz, S.J. (2015), "The economic resilience of US counties during the great recession", Review of Regional Studies, Vol. 45 No. 2, pp. 131-149.

Hennig-Thurau, T., Houston, M.B. and Sridhar, S. (2006), "Can good marketing carry a bad product? Evidence from the motion picture industry”, Marketing Letters, Vol. 17 No. 3, pp. 205-219.

Holt, D.B., Quelch, J.A. and Taylor, E.L. (2004), "How global brands compete", Harvard Business Review, Vol. 82, pp. 68-75. 
Hsu, K.T. (2012), “The advertising effects of corporate social responsibility on corporate reputation and brand equity: evidence from the life insurance industry in Taiwan", Journal of Business Ethics, Vol. 109 No. 2, pp. 189-201.

Hult, G.T.M. (2011), "Toward a theory of the boundary-spanning marketing organization and insights from 31 organization theories", Journal of the Academy of Marketing Science, Vol. 39 No. 4, pp. 509-536.

Hur, W.M., Kim, H. and Woo, J. (2014), "How CSR leads to corporate brand equity: mediating mechanisms of corporate brand credibility and reputation”, Journal of Business Ethics, Vol. 125 No. 1, pp. 75-86.

Ioannou, I. and Flammer, C. (2019), "Save or invest? How companies should navigate recessions", Harvard Business Review, available at: https://hbr.org/2019/05/save-or-invest-how-companiesshould-navigate-recessions

Jin, G.Z. and Leslie, P. (2003), "The effect of information on product quality: evidence from restaurant hygiene grade cards", The Quarterly Journal of Economics, Vol. 118 No. 2, pp. 409-451.

Johansson, J.K., Dimofte, C.V. and Mazvancheryl, S.K. (2012), "The performance of global brands in the 2008 financial crisis: a test of two brand value measures", International Journal of Research in Marketing, Vol. 29 No. 3, pp. 235-245.

Kang, C., Germann, F. and Grewal, R. (2016), "Washing away your sins? Corporate social responsibility, corporate social irresponsibility, and firm performance", Journal of Marketing, Vol. 80 No. 2, pp. 59-79.

Kashmiri, S. and Mahajan, V. (2010), "What's in a name? An analysis of the strategic behavior of family firms", International Journal of Research in Marketing, Vol. 27 No. 3, pp. 271-280.

Kay, M.J. (2006), "Strong brands and corporate brands", European Journal of Marketing, Vol. 40 Nos 7/8, pp. 742-760.

Keller, K.L. (1993), “Conceptualizing, measuring, and managing customer-based brand equity”, Journal of Marketing, Vol. 57 No. 1, pp. 1-22.

Keller, K.L. (2001), Building Customer-Based Brand Equity: A Blueprint for Creating Strong Brands, Marketing Science Institute, Cambridge, MA, pp. 3-27.

Keys, T., Malnight, T.W. and Van Der Graaf, K. (2009), "Making the most of corporate social responsibility”, McKinsey Quarterly, Vol. 36, pp. 38-44.

Kirmani, A. and Rao, A.R. (2000), "No pain, no gain: a critical review of the literature on signaling unobservable product quality", Journal of Marketing, Vol. 64 No. 2, pp. 66-79.

Klein, J. and Dawar, N. (2004), "Corporate social responsibility and consumers' attributions and brand evaluations in a product - harm crisis", International Journal of Research in Marketing, Vol. 21 No. 3, pp. 203-217.

Kotchen, M. and Moon, J.J. (2012), “Corporate social responsibility for irresponsibility”, The BE Journal of Economic Analysis \& Policy, Vol. 12 No. 1.

Lai, C.S., Chiu, C.J., Yang, C.F. and Pai, D.C. (2010), "The effects of corporate social responsibility on brand performance: the mediating effect of industrial brand equity and corporate reputation", Journal of Business Ethics, Vol. 95 No. 3, pp. 457-469.

Lamey, L., Deleersnyder, B., Dekimpe, M.G. and Steenkamp, J.B.E. (2007), "How business cycles contribute to private-label success: evidence from the United States and Europe", Journal of Marketing, Vol. 71 No. 1, pp. 1-15.

Laufer, W.S. (2003), "Social accountability and corporate greenwashing", Journal of Business Ethics, Vol. 43 No. 3, pp. 253-261.

Levine, R., Loayza, N. and Beck, T. (2002), "Financial intermediation and growth: causality and causes", Central Banking, Analysis, and Economic Policies Book Series, Vol. 3, pp. 31-84.

Lewis, V., Kay, K.D., Kelso, C. and Larson, J. (2010), "Was the 2008 financial crisis caused by a lack of corporate ethics?”, Global Journal of Business Research, Vol. 4 No. 2, pp. 77-84. 
Lindgreen, A., Xu, Y., Maon, F. and Wilcock, J. (2012), “Corporate social responsibility brand leadership: a multiple case study", European Journal of Marketing, Vol. 46 Nos 7/8, pp. 965-993.

Lovett, M., Peres, R. and Shachar, R. (2014), “A data set of brands and their characteristics”, Marketing Science, Vol. 33 No. 4, pp. 609-617.

Ludvigson, S.C. (2004), "Consumer confidence and consumer spending", Journal of Economic Perspectives, Vol. 18 No. 2, pp. 29-50.

Luo, X. and Bhattacharya, C.B. (2006), "Corporate social responsibility, customer satisfaction, and market value", Journal of Marketing, Vol. 70 No. 4, pp. 1-18.

Luo, X. and Bhattacharya, C.B. (2009), "The debate over doing good: corporate social performance, strategic marketing levers, and firm-idiosyncratic risk", Journal of Marketing, Vol. 73 No. 6, pp. 198-213.

Luo, X. and Homburg, C. (2007), "Neglected outcomes of customer satisfaction", Journal of Marketing, Vol. 71 No. 2, pp. 133-149.

Luo, X., Zhang, R., Zhang, W. and Aspara, J. (2014), "Do institutional investors pay attention to customer satisfaction and why?", Journal of the Academy of Marketing Science, Vol. 42 No. 2, pp. 119-136.

McAlister, L., Srinivasan, R., Jindal, N. and Cannella, A.A. (2016), “Advertising effectiveness: the moderating effect of firm strategy", Journal of Marketing Research, Vol. 53 No. 2, pp. 207-224.

McWilliams, A. and Siegel, D. (2001), "Corporate social responsibility: a theory of the firm perspective", Academy of Management Review, Vol. 26 No. 1, pp. 117-127.

McWilliams, A., Siegel, D.S. and Wright, P.M. (2006), "Corporate social responsibility: strategic implications", Journal of Management Studies, Vol. 43 No. 1, pp. 1-18.

Madden, T.J., Roth, M.S. and Dillon, W.R. (2012), "Global product quality and corporate social responsibility perceptions: a cross-national study of halo effects", Journal of International Marketing, Vol. 20 No. 1, pp. 42-57.

Melo, T. and Galan, J.I. (2011), "Effects of corporate social responsibility on brand value", Journal of Brand Management, Vol. 18 No. 6, pp. 423-437.

Mishra, S. and Modi, S.B. (2016), "Corporate social responsibility and shareholder wealth: the role of marketing capability", Journal of Marketing, Vol. 80 No. 1, pp. 26-46.

Mizik, N. and Jacobson, R. (2008), "The financial value impact of perceptual brand attributes", Journal of Marketing Research, Vol. 45 No. 1, pp. 15-32.

Mizik, N. and Jacobson, R. (2014), "Assessing the total financial performance impact of brand equity with limited time-series data", Journal of Marketing Research, Vol. 51 No. 6, pp. 691-706.

Moosmayer, D.C. and Fuljahn, A. (2013), "Corporate motive and fit in cause related marketing”, Journal of Product and Brand Management, Vol. 22 No. 3, pp. 200-207.

National Bureau of Economic Research (2010), “The NBER's recession dating procedure”, available at: https://www.nber.org/cycles/jan08bcdc_memo.html

Neville, B.A., Bell, S.J. and Mengüç, B. (2005), "Corporate reputation, stakeholders and the social performance-financial performance relationship", European Journal of Marketing, Vol. 39 Nos 9/10, pp. 1184-1198.

Nicolau, J.L. (2008), “Corporate social responsibility: worth-creating activities", Annals of Tourism Research, Vol. 35 No. 4, pp. 990-1006.

O'Malley, L., Story, V. and O'Sullivan, V. (2011), "Marketing in a recession: retrench or invest?", Journal of Strategic Marketing, Vol. 19 No. 3, pp. 285-310.

Oh, H., Oh, H., Bae, J., Bae, J., Currim, I.S., Currim, I.S. and Zhang, Y. (2016), "Marketing spending, firm visibility, and asymmetric stock returns of corporate social responsibility strengths and concerns", European Journal of Marketing, Vol. 50 Nos 5/6, pp. 838-862. 
Özturan, P., Özsomer, A. and Pieters, R. (2014), "The role of market orientation in advertising spending during economic collapse: the case of Turkey in 2001", Journal of Marketing Research, Vol. 51 No. 2, pp. 139-152.

Peng, M.W. and Luo, Y. (2000), "Managerial ties and firm performance in a transition economy: the nature of a micro-macro link", Academy of Management Journal, Vol. 43 No. 3, pp. 486-501.

Piercy, N.F., Cravens, D.W. and Lane, N. (2010), "Marketing out of the recession: recovery is coming, but things will never be the same again", The Marketing Review, Vol. 10 No. 1, pp. 3-23.

Porter, M.E. and Kramer, M.R. (2006), "Strategy and society", Harvard Business Review, Vol. 84 No. 12, pp. 78-92.

Putte, B.V.D. (2009), "What matters most in advertising campaigns? The relative effect of media expenditure and message content strategy", International Journal of Advertising, Vol. 28 No. 4, pp. 669-690.

Quelch, J. (2008), "Marketing your way through a recession”, Harvard Business School Blog, available at: https://hbswk.hbs.edu/item/marketing-your-way-through-a-recession

Quelch, J. and Jocz, K.E. (2009), "How to market in a downturn", Harvard Business Review, Vol. 87 No. 4, pp. 52-62.

Raggio, R.D. and Leone, R.P. (2009), "Postscript: preserving (and growing) brand value in a downturn”, Journal of Brand Management, Vol. 17 No. 1, pp. 84-89.

Rego, L.L., Billett, M.T. and Morgan, N.A. (2009), “Consumer-based brand equity and firm risk”, Journal of Marketing, Vol. 73 No. 6, pp. 47-60.

Rego, L.L., Morgan, N.A. and Fornell, C. (2013), "Reexamining the market share - customer satisfaction relationship", Journal of Marketing, Vol. 77 No. 5, pp. 1-20.

Ricks, J.M. Jr, (2005), "An assessment of strategic corporate philanthropy on perceptions of brand equity variables”, Journal of Consumer Marketing, Vol. 22 No. 3, pp. 121-134.

Roodman, D. (2009), "A note on the theme of too many instruments", Oxford Bulletin of Economics and Statistics, Vol. 71 No. 1, pp. 135-158.

Rothenberg, S. and Zyglidopoulos, S.C. (2007), "Determinants of environmental innovation adoption in the printing industry: the importance of task environment", Business Strategy and the Environment, Vol. 16 No. 1, pp. 39-49.

Rust, R.T., Lemon, K.N. and Zeithaml, V.A. (2004), "Return on marketing: using customer equity to focus marketing strategy", Journal of Marketing, Vol. 68 No. 1, pp. 109-127.

Saxton, G.D., Gomez, L., Ngoh, Z., Lin, Y.P. and Dietrich, S. (2019), "Do CSR messages resonate? Examining public reactions to firms' CSR efforts on social media", Journal of Business Ethics, Vol. 155 No. 2, pp. 359-377.

Sen, S. and Bhattacharya, C.B. (2001), "Does doing good always lead to doing better? Consumer reactions to corporate social responsibility”, Journal of Marketing Research, Vol. 38 No. 2, pp. 225-243.

Sierra, V., Iglesias, O., Markovic, S. and Singh, J.J. (2017), "Does ethical image build equity in corporate services brands? The influence of customer perceived ethicality on affect, perceived quality, and equity”, Journal of Business Ethics, Vol. 144 No. 3, pp. 661-676.

Smith, W. and Higgins, M. (2000), "Cause-related marketing: ethics and the ecstatic", Business and Society, Vol. 39 No. 3, pp. 304-322.

Spence, M. (1978), “Job market signaling”, Uncertainty in Economics, Academic Press, pp. 281-306.

Srinivasan, R., Lilien, G.L. and Sridhar, S. (2011), "Should firms spend more on research and development and advertising during recessions?", Journal of Marketing, Vol. 75 No. 3, pp. 49-65.

Srinivasan, S., Vanhuele, M. and Pauwels, K. (2010), "Mindset metrics in market response models: an integrative approach", Journal of Marketing Research, Vol. 47 No. 4, pp. 672-684.

Steenkamp, J.B.E., Van Heerde, H.J. and Geyskens, I. (2010), "What makes consumers willing to pay a price premium for national brands over private labels?”, Journal of Marketing Research, Vol. 47 No. 6, pp. 1011-1024. 
Stock, J.H. and Watson, M.W. (2012), "Disentangling the channels of the 2007-2009 recession", No. w18094, National Bureau of Economic Research.

Tellis, G.J. and Tellis, K. (2009), "Research on advertising in a recession", Journal of Advertising Research, Vol. 49 No. 3, pp. 304-327.

Thomas, S. (2002), "Firm diversification and asymmetric information: evidence from analysts' forecasts and earnings announcements", Journal of Financial Economics, Vol. 64 No. 3, pp. 373-396.

Thorne, L., Mahoney, L.S., Gregory, K. and Convery, S. (2017), "A comparison of Canadian and US CSR strategic alliances, CSR reporting, and CSR performance: insights into implicit - explicit CSR", Journal of Business Ethics, Vol. 143 No. 1, pp. 85-98.

Tingchi Liu, M., Anthony Wong, I., Shi, G., Chu, R. and L. Brock, J. (2014), "The impact of corporate social responsibility (CSR) performance and perceived brand quality on customer-based Brand preference", Journal of Services Marketing, Vol. 28 No. 3, pp. 181-194.

Torres, A., Bijmolt, T.H., Tribó, J.A. and Verhoef, P. (2012), "Generating global brand equity through corporate social responsibility to key stakeholders", International Journal of Research in Marketing, Vol. 29 No. 1, pp. 13-24.

Tuli, K.R. and Bharadwaj, S.G. (2009), "Customer satisfaction and stock returns risk", Journal of Marketing, Vol. 73 No. 6, pp. 184-197.

Tuli, K.R., Bharadwaj, S.G. and Kohli, A.K. (2010), "Ties that bind: the impact of multiple types of ties with a customeron sales growth and sales volatility", Journal of Marketing Research, Vol. 47 No. 1, pp. 36-50.

Udayasankar, K. (2008), "Corporate social responsibility and firm size”, Journal of Business Ethics, Vol. 83 No. 2, pp. 167-175.

Van de Ven, B. and Jeurissen, R. (2005), "Competing responsibly", Business Ethics Quarterly, Vol. 15 No. 2, pp. 299-317.

Van Heerde, H.J., Gijsenberg, M.J., Dekimpe, M.G. and Steenkamp, J.B.E. (2013), "Price and advertising effectiveness over the business cycle”, Journal of Marketing Research, Vol. 50 No. 2, pp. 177-193.

Van Steenburg, E. and Spears, N. (2011), "Understanding the relationship between brand loyalty, the prevailing economic environment and optimum stimulation level", Journal of Brand Management, Vol. 18 No. 8, pp. 597-610.

Werther, W.B., Jr,. and Chandler, D. (2005), "Strategic corporate social responsibility as global brand insurance", Business Horizons, Vol. 48 No. 4, pp. 317-324.

Wood, L. (2000), "Brands and brand equity: definition and management", Management Decision, Vol. 38 No. 9, pp. 662-669.

Yim, S., Bae, Y.H., Lim, H. and Kwon, J. (2019), "The role of marketing capability in linking CSR to corporate financial performance: when CSR gives positive signals to stakeholders", European Journal of Marketing, Vol. 53 No. 7, pp. 1333-1354.

Zerbini, F. (2017), "CSR initiatives as market signals: a review and research agenda”, Journal of Business Ethics, Vol. 146 No. 1, pp. 1-23.

\section{Further reading}

Amit, R., Domowitz, I. and Fershtman, C. (1988), "Thinking one step ahead: the use of conjectures in competitor analysis", Strategic Management Journal, Vol. 9 No. 5, pp. 431-442.

Barnett, M.L. and Salomon, R.M. (2012), "Does it pay to be really good? Addressing the shape of the relationship between social and financial performance", Strategic Management Journal, Vol. 33 No. 11, pp. 1304-1320.

Bondy, T. and Talwar, V. (2011), "Through thick and thin: how fair trade consumers have reacted to the global economic recession”, Journal of Business Ethics, Vol. 101 No. 3, pp. 365-383. 
Brammer, S. and Millington, A. (2008), "Does it pay to be different? An analysis of the relationship between corporate social and financial performance", Strategic Management Journal, Vol. 29 No. 12, pp. 1325-1343.

Gerzema, J. and D'Antonio, M. (2010), Spend Shift: How the Post-Crisis Values Revolution is Changing the Way we Buy, Sell, and Live, John Wiley and Sons.

Griffin, J.J. and Mahon, J.F. (1997), "The corporate social performance and corporate financial performance debate: twenty-five years of incomparable research", Business and Society, Vol. 36 No. 1, pp. 5-31.

Grusky, D.B., Western, B. and Wimer, C. (Eds) (2011), "The consequences of the great recession", The

Doing good when times are bad Great Recession, Russell Sage, New York, NY, pp. 3-20.

Hamilton, R.W., Thompson, D.V., Arens, Z.G., Blanchard, S.J., Häubl, G., Kannan, P.K., Khan, U., Lehmann, D.R., Meloy, M.G., Roese, N.J. and Thomas, M. (2014), "Consumer substitution decisions: an integrative framework", Marketing Letters, Vol. 25 No. 3, pp. 305-317.

Hull, C.E. and Rothenberg, S. (2008), "Firm performance: the interactions of corporate social performance with innovation and industry differentiation", Strategic Management Journal, Vol. 29 No. 7 , pp. $781-789$.

Jayachandran, S., Kalaignanam, K. and Eilert, M. (2013), "Product and environmental social performance: varying effect on firm performance", Strategic Management Journal, Vol. 34 No. 10, pp. 1255-1264.

Katsikeas, C.S., Morgan, N.A., Leonidou, L.C. and Hult, G.T.M. (2016), “Assessing performance outcomes in marketing", Journal of Marketing, Vol. 80 No. 2, pp. 1-20.

Leonidou, L.C., Kvasova, O., Leonidou, C.N. and Chari, S. (2013), "Business unethicality as an impediment to consumer trust: the moderating role of demographic and cultural characteristics", Journal of Business Ethics, Vol. 112 No. 3, pp. 397-415.

Lin, C.P., Chen, S.C., Chiu, C.K. and Lee, W.Y. (2011), "Understanding purchase intention during product-harm crises: moderating effects of perceived corporate ability and corporate social responsibility", Journal of Business Ethics, Vol. 102 No. 3, p. 455.

Meijer, M.M. and Schuyt, T. (2005), "Corporate social performance as a bottom line for consumers", Business and Society, Vol. 44 No. 4, pp. 442-461.

Mohr, L.A., Webb, D.J. and Harris, K.E. (2001), "Do consumers expect companies to be socially responsible? The impact of corporate social responsibility on buying behavior", Journal of Consumer Affairs, Vol. 35 No. 1, pp. 45-47.

Ocasio, W.C. (1995), "The enactment of economic adversity: a reconciliation of theories of failureinduced change and threat-rigidity”, Research in Organizational Behavior, Vol. 17, pp. 287-331.

Orlitzky, M., Schmidt, F.L. and Rynes, S.L. (2003), “Corporate social and financial performance: a metaanalysis”, Organization Studies, Vol. 24 No. 3, pp. 403-441.

Srivastava, R.K., Shervani, T.A. and Fahey, L. (1998), "Market-based assets and shareholder value: a framework for analysis", Journal of Marketing, Vol. 62 No. 1, pp. 2-18.

\section{Corresponding author}

Abhi Bhattacharya can be contacted at: abhi.bhattacharya@rug.nl

For instructions on how to order reprints of this article, please visit our website:

www.emeraldgrouppublishing.com/licensing/reprints.htm

Or contact us for further details: permissions@emeraldinsight.com 